\title{
KLASIFIKASI HABITAT PERAIRAN DANGKAL DARI CITRA MULTISPASIAL DI PERAIRAN PULAU KAPOTA DAN PULAU KOMPOONE, KEPULAUAN WAKATOBI
}

\section{BENTHIC HABITAT CLASSIFICATION ON MULTISPATIAL SATELLITE IMAGERY IN KAPOTA AND KOMPOONE ISLANDS, WAKATOBI}

\author{
Vincentius P. Siregar*, Syamsul B. Agus, Adriani Sunuddin, Riza A. Pasaribu, \\ M. Siddiq Sangadji, \& Esty Kurniawati \\ Departemen Ilmu dan Teknologi Kelautan, FPIK-IPB Univeristy, Bogor, 16680, Indonesia \\ *E-mail: vingar2016@gmail.com
}

\begin{abstract}
Shallow water habitat mapping is important to do because: (1) it can support the planning, management, and decision making of government spatial; (2) it can support and design a Marine Protected Area (MPA); (3) it can conduct a scientific research program to determine a knowledge about benthic ecosystem and seabed geology; (4) it can do seabed resource valuation, both biotic and abiotic, for economic and management goals. Nowadays, the standardization of thematic map details level in coastal ecosystem has not determined, especially in shallow water habitat based on coastal management needs in certain scale. The study aims to compare map accuracy level between SPOT 6, Sentinel 2A, and Landsat 8 classification results using support vector machine algorithm. The study site is in Wakatobi Island, including Kapota Island and Kompoone Island. The in-situ data took on July 2019. The 347 ground truth and transect images in the field analyzed using Coral Point Count with Excel Extension (CPCe). The classification scheme that was gotten is 8 habitat benthic classes, then conducted classification with classify them to be 6 and 5 classes. The result from SPOT 6 for 5 habitat classes has the highest overall accuracy. The differences between pixel (spatial resolution) and the amount of classification scheme influence accuracy results.
\end{abstract}

Keywords: multi-scales mapping, satellite imagery, shallow water habitat

\begin{abstract}
ABSTRAK
Habitat perairan dangkal sangat penting dipetakan diantaranya karena: (1) mendukung perencanaan, manajemen, dan pengambilan keputusan tata ruang pemerintah; (2) mendukung dan mendesain Marine Protected Area (MPA); (3) melakukan program penelitian ilmiah yang bertujuan untuk menghasilkan pengetahuan tentang ekosistem bentik dan geologi dasar laut; (4) melakukan penilaian sumber daya dasar laut yang hidup dan tidak hidup untuk tujuan ekonomi dan menajemen, termasuk rancangan cadangan perikanan. Hingga saat ini belum ada standar untuk tingkat kedetailan peta tematik ekosistem pesisir khususnya habitat perairan dangkal sesuai kebutuhan pengelolaan wilayah pesisir dengan skema klasifikasi tertentu. Penelitian ini bertujuan untuk membandingkan akurasi peta hasil klasifikasi habitat perairan dangkal antara citra SPOT 6, Sentinel 2A, dan Landsat 8 menggunakan algoritma klasifikasi support vector machine. Lokasi penelitian terletak di Kepulauan Wakatobi, meliputi 2 lokasi yaitu Pulau Kapota dan Pulau Kompoone. Pengambilan data in-situ dilaksanakan pada tanggal 7-11 Juli 2019. Sebanyak 347 ground truth dan foto transek hasil sampling di lapangan telah dianalisis menggunakan coral point count with excel extension (CPCe). Skema klasifikasi yang dihasilkan yaitu 8 kelas habitat bentik, selanjutnya dilakukan klasifikasi dengan mengkelaskan kembali menjadi 6 dan 5 kelas. Hasil yang diperoleh pada citra SPOT-6 untuk semua kelas habitat perairan dangkal yang digunakan memiliki overall accuracy yang lebih besar. Perbedaan ukuran piksel (resolusi spasial) dan jumlah skema klasifikasi sangat memengaruhi hasil akurasi.
\end{abstract}

Kata Kunci: citra satelit, habitat perairan dangkal, pemetaan multiskala 


\section{PENDAHULUAN}

Dalam lingkup pengindraan jauh, perairan laut dangkal merupakan wilayah laut dari batas pantai sampai dengan kedalaman tertentu yang merujuk pada kemampuan energi matahari dalam menembus kolom perairan (Mumby et al., 2003). Khusus untuk perairan laut dangkal yang jernih, metode pengindraan jauh optik mampu mengindra kedalaman perairan antara 15-30 m (Mumby et al., 2003). Sehingga, berbagai habitat perairan dangkal mampu dideteksi oleh sensor satelit diantaranya substrat, lamun, terumbu karang, dan alga (Laffoley \& Grimsditch, 2009).

Habitat perairan dangkal meliputi lingkungan alam di mana organisme atau komunitas hidup, atau lingkungan fisik yang mengelilinginya (pengaruh dan dimanfaatkan oleh) spesies atau komunitas (Harris et $a l$. , 2012). Habitat perairan dangkal mempunyai fungsi penting, baik secara ekologis maupun ekonomis. Fungsi tersebut diantaranya sebagai sumber plasma nutfah dan biodiversitas bagi kehidupan laut, tempat mencari makan, bertelur dan berpijah bagi banyak biota laut, sebagai perlindungan pantai dari gelombang, penstabil sedimen dan penjernih air, penyerap karbon, sumber material untuk farmasi dan industri, serta fungsi pariwisata (Laffoley \& Grimsdich, 2009).

Teknik umum untuk memetakan habitat perairan dangkal telah banyak dilakukan melalui sampling lapangan dan foto udara. Namun membutuhkan waktu, tenaga, biaya yang mahal, dan terbatas di daerah liputannya (Eugenio et al., 2015). Oleh karena itu, citra satelit menjadi sangat penting bagi pemantauan habitat perairan dangkal, dan saat ini data very high resolution (VHR) menawarkan peluang baru diantaranya kemampuan sensor dalam mendeteksi objek secara detail (Lyons et al., 2011).

Kemampuan sensor satelit pengindraan jauh dalam mendeteksi habitat perairan dangkal berbeda-beda sesuai dengan karakteristik sensor, salah satunya seperti resolusi spasial (Siregar et al., 2020). Pada citra satelit SPOT memiliki resolusi spasial 6 meter, 10 meter untuk Sentinel 2 dan 30 m untuk Landsat (Wei et al., 2017; Mandanici \& Bitelli, 2016). Umumnya banyak digunakan dalam pemetaan habitat perairan dangkal. Karena, selain harganya yang terjangkau seperti citra SPOT, Sentinel 2 dan Landsat dapat diperoleh dengan gratis (Prabowo et al., 2018; Traganos \& Reinartz, 2017; Benfield et al., 2007).

Penelitian mengenai habitat perairan dangkal menggunakan citra satelit SPOT, Sentinel 2 dan Landsat telah banyak dilakukan dalam memberikan informasi habitat perairan dangkal seperti pemetaan terumbu karang dan kaitannya dengan habitat sub-litoral menggunakan citra satelit Landsat (Benfield et al., 2007), pemetaan lamun menggunakan Sentinel 2 (Traganos \& Reinartz, 2017); Perbandingan Landsat ETM+, SPOT HRV, Ikonos, ASTER, dan airborne dalam memetakan habitat terumbu karang di Pulau Pasifik Selatan (Capolsini et al., 2003), penggunaan Sentinel 2 dalam memetakan terumbu karang dan medeteksi bleaching coral (Hedley et al., 2012), dan pemetaan lamun menggunakan Landsat TM $(\mathrm{Pu}$ et al., 2014).

Di Indonesia, pemanfaatan citra satelit untuk mengkaji habitat perairan dangkal juga telah banyak dilakukan diantaranya pemetaan habitat dasar perairan dangkal dari citra SPOT-7 menggunakan metode object based image analysis (OBIA) di pulau Harapan dan pulau Kelapa (Prabowo et al., 2018), deteksi perubahan hamparan terumbu karang menggunakan Landsat 8 di Maluku Utara (Wahidin et al., 2015), dan pemetaan habitat perairan dangkal menggunakan Sentinel 2A dengan metode OBIA di perairan Wangi-Wangi (Mastu et al., 2018). Tujuan dari penelitian ini adalah untuk mengetahui keragaman citra satelit dengan resolusi spasial yang berbeda dalam memetakan habitat perairan dangkal menggunakan citra satelit SPOT 6, Sentinel 2, dan Landsat 8 untuk beberapa skema klasifikasi dengan 
menerapkan algoritma support vector machine.

\section{METODE PENELITIAN}

\subsection{Waktu dan Lokasi Penelitian}

Penelitian dilakukan di Pulau Kapota dan Pulau Kompoone (Figure 1). Pengambilan data lapang dilaksanakan selama 5 hari yaitu pada tanggal 7 hingga 11 Juli 2019. Pelaksanaan penelitian dimulai dari persiapan dan pengumpulan data sekunder dan survei lapangan untuk mengumpulkan data in-situ. Selanjutnya, data lapangan yang dikumpulkan melalui teknik foto transek dianalisis untuk membangun skema klasifikasi kelas habitat.

\subsection{Alat dan Bahan}

Peralatan yang digunakan pada penelitian ini meliputi perangkat keras, perangkat lunak, dan peralatan pengambilan data di lapangan. Peralatan yang digunakan dalam melakukan pengumpulan dan pengolahan data dalam penelitian ini disajikan pada Table 1 .

\subsection{Metode Pengambilan dan Pra- Pengolah Data}

Pengumpulan data lapang meliputi pencatatan posisi geografis, identifikasi objek dan persen penutupan. Koordinat titik sampel diambil menggunakan GPS Garmin 76 CSX.

Pengamatan habitat dasar perairan dangkal dilakukan dengan cara snorkeling dan transek kudrat untuk identifikasi dan persen penutupan habitat. Rangkaian prapengolahan data citra terdiri dari beberapa tahapan, yaitu: koreksi geometrik, koreksi radiometrik, koreksi atmosferik, dan koreksi sun glint (Doxani et al., 2012).

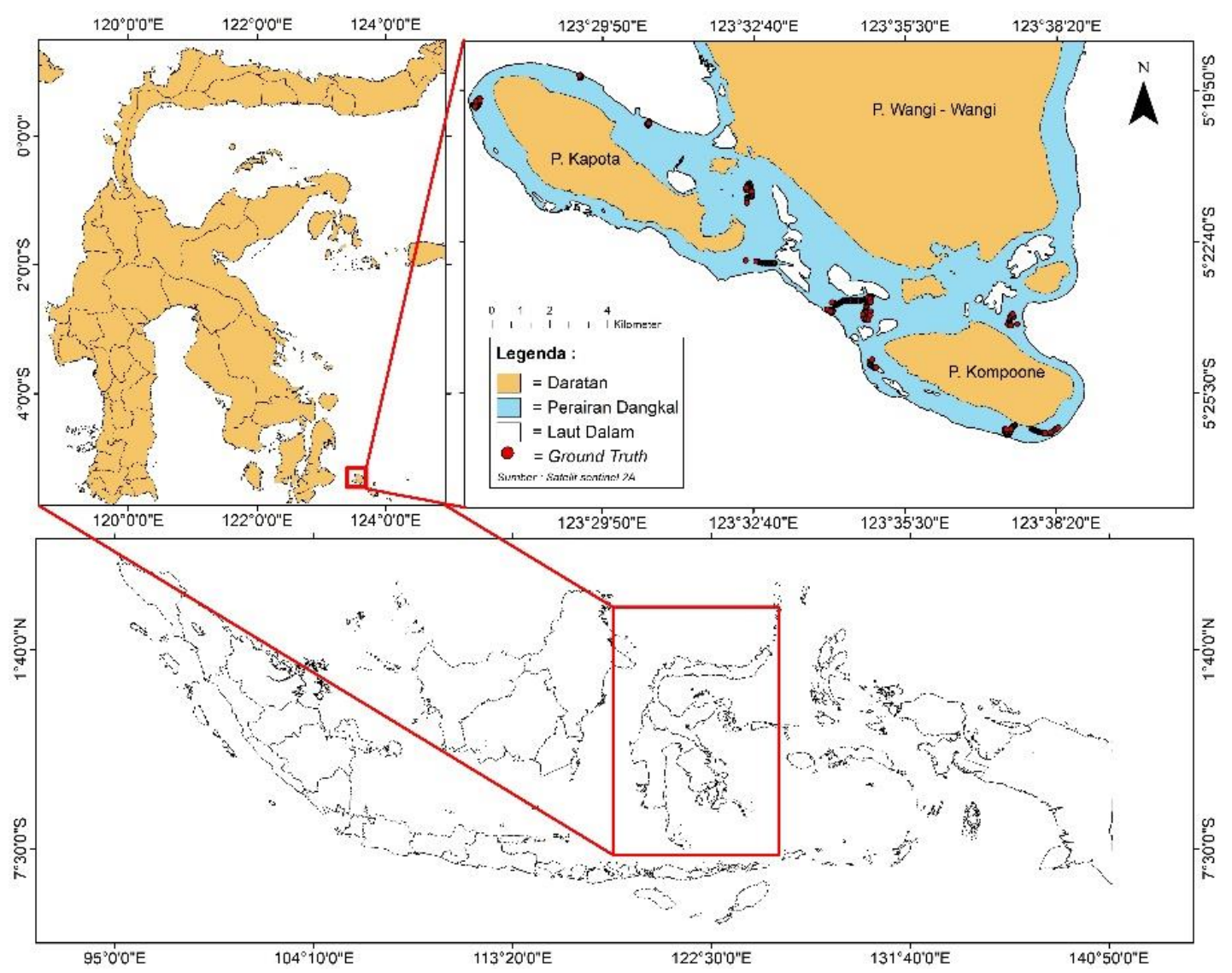

Figure 1. Research location in Kapota and Kompoone Island, Wakatobi, South East Sulawesi, Indonesia. 
Tabel 1. List of equipment to be used for conducting research.

\begin{tabular}{|c|c|c|}
\hline No. & Equipment & Function \\
\hline \multicolumn{3}{|c|}{ Equipment of data collection } \\
\hline 1. & Garmin GPS hand held & Recording position when field data collection \\
\hline 2. & Transect quadrat & Retrieval of benthic habitat data \\
\hline 3. & Meter roll $50 \mathrm{~m}$ & Retrieval of benthic habitat data \\
\hline 4. & Camera and underwater housing & Taking photos of habitats \\
\hline 5. & Diving equipment & Retrieval of benthic habitat data in water \\
\hline 6. & Floating GPS & For GPS buoy \\
\hline 7. & Working map & Reference when conducting surveys \\
\hline & Dry bag & Storing the equipment susceptible to water \\
\hline \multicolumn{3}{|c|}{ Satelitte Imagery } \\
\hline 1 & SPOT-6 & $\begin{array}{l}\text { Data analysis (acquisition date } 23 \text { March 2019; } \\
\text { Path 4254-Row 2933) }\end{array}$ \\
\hline 2 & Sentinel $2 A$ & $\begin{array}{l}\text { Data analysis (acquisition date } 23 \text { July 2019; } \\
\text { Path 2314-Row 1460) }\end{array}$ \\
\hline 3 & Landsat 8 OLI & $\begin{array}{l}\text { Data analysis (acquisition date } 12 \text { July 2019; } \\
\text { Path 111-Row 64) }\end{array}$ \\
\hline \multicolumn{3}{|c|}{ Data processing } \\
\hline 1. & Microsoft Excel + Xlstat & Tabulate data \\
\hline 2. & СРCe 4.1 & Transect photo data processing \\
\hline 3. & QGIS 3.8 Zanzibar & Satelitte data processing \\
\hline 4. & ArcGIS Desktop 10.4 & Visualization and layouting map \\
\hline
\end{tabular}

\subsection{Analisis Data}

\subsubsection{Skema Klasifikasi}

Penentuan skema klasifikasi didapat dari hasil Agglomerative Hierarchical Clustering (AHC) dengan menggunakan data hasil pengamatan foto transek di lokasi penelitian. Analisis AHC merupakan analisis berdasarkan nilai ketidakmiripan (dissimilarities) antara objek yang akan dikelompokan. Adapun analisis ketidakmiripan dilakukan dengan bantuan perangkat lunak XLSTAT, dengan parameter: Proximity Type $=$ Dissimilarities (Bray and Curtis Distance); Agglomeration method= Unweighted pair-group average; Truncation $=$ Level $(0,4)$ dan Number of Classes (8); Dendrogram = Vertical .

Kemiripan diukur dengan menggunakan jarak kemiripan Bray-Curtis karena mampu membedakan dan mengkelaskan data dengan jumlah yang banyak menjadi kelas-kelas data yang seragam. Belum ada standardisasi dalam penentuan nilai dis- similarities untuk mengidentifikasi skema klasifikasi habitat bentik, hal ini menyesuaikan dengan platform citra satelit yang digunakan (Green et al., 2000).

\subsubsection{Klasifikasi Habitat Perairan Dangkal}

Klasifikasi habitat perairan dangkal ini menggunakan metode berbasis piksel yang merupakan klasifikasi berdasarkan informasi per piksel, di mana setiap piksel diklasifikasi menjadi satu kategori. Algoritma klasifikasi yang digunakan adalah algoritma SVM dengan tipe kernel radial basis function (RBF). Persamaannya dapat ditulis sebagai berikut:

$f(x)=\sum_{i \in S} \lambda_{i} y_{i} K\left(x_{i} x\right)+w_{0}$

Keterangan: $K$ merupakan fungsi kernel, $y_{i}$ dan $x_{i}$ mewakili training sample, $\lambda_{i}$ merupakan pengganda Lagrange, $S$ bagian dari training sample yang sesuai dengan 
pengganda Lagrange non-zero, dan wo adalah parameter hyperplane (Mountrakis et al., 2011).

\subsubsection{Uji Akurasi Hasil Klasifikasi}

Hasil klasifikasi data pengindraan jauh divalidasi menggunakan sebuah matriks kesalahan (error matrix) seperti yang ditampilkan pada Figure 2. Hal ini dilakukan dengan membandingkan citra hasil klasifikasi sebagai peta terhadap kelas yang sebenarnya. Kelas yang sebenarnya diperoleh dari hasil pengamatan lapangan. Uji akurasi mengacu kepada Congalton \& Green (2008).

Keterangan: $n_{i+}=\sum_{j=1}^{k} n_{i j}$ merupakan jumlah sampel hasil klasifikasi terhadap kelas I dalam klasifikasi pengindraan jauh, dan $n_{+j}=\sum_{j=1}^{k} n_{i j}$ merupakan jumlah sampel yang diklasifikasikan ke kelas $j$ pada data referensi. Akurasi keseluruhan (overall accuracy) antara data hasil klasifikasi pengindraan jauh dan data referensi dapat dihitung sebagai berikut:

Overall accuracy $=\frac{\sum_{i=1}^{k} n_{i i}}{n}$

Producer's accuracy $j=\frac{n_{j j}}{n_{+j}}$

User's accuracy $i=\frac{n_{i i}}{n_{i+}}$
Sebuah uji-Z berbasis KHAT atau statistik K (Kappa) akan digunakan untuk menilai akurasi klasifikasi dari sebuah matriks kesalahan. Nilai koefisien Kappa (KHAT statistik) berada pada rentang 0 hingga 1 dan biasanya akan lebih kecil dari nilai akurasi keseluruhan, dan dapat dihitung menggunakan:

$K=\frac{N \sum_{i=1}^{k} n_{i i}-\sum_{i=1}^{k} n_{i+} n_{+i}}{N^{2}-\sum_{i=1}^{k} n_{i+} n_{+i}}$

Keterangan: $k$ adalah jumlah baris pada matriks, $n_{i i}$ adalah jumlah pengamatan pada baris $i$ dan kolom $i, n_{i+}$ dan $n_{+i}$ adalah total margin baris $i$ dan kolom $i, N$ adalah jumlah pengamatan. $\mathrm{K}$ menyatakan pengurangan dalam kesalahan yang keseluruhan merupakan klasifikasi acak. Misalnya nilai $\mathrm{K}$ adalah 0,80 maka proses klasifikasi yang dilakukan menghindari 80\% kesalahan klasifikasi acak.

Penentuan dua nilai Kappa independen dan untuk dua matriks kesalahan yang secara signifikan berbeda, maka digunakan uji yang memungkinkan perbandingan secara statistik dua analisis, analisis yang sama dengan waktu berbeda, dua algoritma, dua tipe citra, atau dua citra yang sama dalam menghasilkan akurasi lebih baik. Matriks ke-

$$
j=\text { column (reference data) }
$$

\begin{tabular}{|c|c|c|c|c|c|}
\hline & 1 & 2 & 3 & & $\begin{array}{c}\text { Row } \\
\text { Total } \\
n_{i+}\end{array}$ \\
\hline \multirow{2}{*}{ 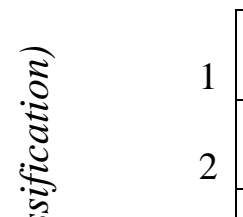 } & $\mathrm{n}_{11}$ & $\mathrm{n}_{12}$ & $\mathrm{n}_{13}$ & $\mathrm{n}_{1 \mathrm{k}}$ & $\mathrm{n}_{1+}$ \\
\hline & $\mathrm{n}_{21}$ & $\mathrm{n}_{22}$ & $\mathrm{n}_{23}$ & $\mathrm{n}_{2 \mathrm{k}}$ & $\mathrm{n}_{2+}$ \\
\hline 3 & $\mathrm{n}_{31}$ & $\mathrm{n}_{32}$ & $\mathrm{n}_{33}$ & $\mathrm{n}_{3 \mathrm{k}}$ & $\mathrm{n}_{3+}$ \\
\hline ?े & $\mathrm{n}_{\mathrm{k} 1}$ & $\mathrm{n}_{\mathrm{k} 2}$ & $\mathrm{n}_{\mathrm{k} 3}$ & $\mathrm{n}_{\mathrm{kk}}$ & $\mathrm{n}_{\mathrm{k}+}$ \\
\hline 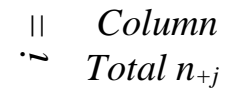 & $\mathrm{n}_{+1}$ & $\mathrm{n}_{+2}$ & $\mathrm{n}_{+3}$ & $\mathrm{n}_{+4}$ & $\mathrm{n}$ \\
\hline
\end{tabular}

Figure 2. Error Matrix. 
salahan tunggal dan pasangan matriks kesalahan diuji tingkat kepercayaan signifikan pada standar deviasi normal sebagai berikut: jika $\check{K}_{1}$ dan $\check{K}_{2}$ merupakan estimasi Kappa statistik dari masing masing matriks kesalahan \#1 dan \#2, var $\left(\check{K}_{l}\right)$ dan $\operatorname{var}\left(\check{K}_{2}\right)$ adalah estimasi varian sebagai hasil perhitungan yang tepat, maka uji statistik menggunakan persamaan:

$\mathrm{Z}=\frac{\check{\mathrm{K}}_{1}}{\sqrt{\operatorname{Var}\left(\check{\mathrm{K}}_{1}\right)}}$

$\mathrm{Z}$ adalah standardisasi dan distribusi normal (standar deviasi) dengan hipotesis $H_{0}: K_{l}=0$ dan $H_{1}: K_{l} \neq 0, H_{0}$ ditolak jika $Z \geq$ $Z_{\alpha / 2}$ dimana $\alpha / 2$ adalah tingkat kepercayaan uji $\mathrm{Z}$ dan derajat bebas diasumsikan tidak terhingga $(\infty)$. Uji statistik untuk menguji jika dua error matrix independen berbeda secara signifikan menggunakan persamaan:

$\mathrm{Z}=\frac{\left|\check{\mathrm{K}}_{1}-\check{\mathrm{K}}_{2}\right|}{\sqrt{\operatorname{Var}\left(\check{\mathrm{K}}_{1}\right)+\operatorname{Var}\left(\check{\mathrm{K}}_{1}\right)}}$

$\mathrm{Z}$ adalah standardisasi distribusi normal nilai Kappa dengan hipotesis $H_{0}$ : $\left(K_{1}-K_{2}\right)=0$, alternatif $H_{1}:\left(K_{1}-K_{2}\right) \neq 0, H_{0}$ ditolak jika $Z \geq Z_{\alpha / 2}$.

\section{HASIL DAN PEMBAHASAN}

\subsection{Skema Klasifikasi}

Data foto transek hasil pengamatan lapangan sejumlah 347 foto dianalisis dan disusun dalam bentuk basis data penelitian. Basis data disusun dengan struktur data meliputi kode data, nomor plot transek, kode GPS, tanggal, waktu, lokasi, site, kode foto, folder path, dan hasil analisis penutupan habitat. Hal ini untuk memudahkan dalam menelusuri metadata penelitian. Penutupan habitat meliputi persentase antara kategori: karang hidup (KH), karang mati $(\mathrm{KH})$, patahan karang (PK), lamun (LM), makroalga (AL), pasir (PS) yang dapat dilihat pada
Figure 3. Kemudian dianalisis menggunakan analisis AHC yang merupakan analisis berdasarkan nilai ketidakmiripan (dissimilarities) antara objek yang akan dikelompokkan.

Kemiripan diukur dengan menggunakan jarak kemiripan Bray-Curtis karena mampu membedakan dan mengkelaskan data dengan jumlah yang banyak menjadi kelas-kelas data yang seragam. Belum ada standardisasi dalam penentuan nilai dissimilarities untuk mengidentifikasi skema klasifikasi bentik habitat karena butuh penyesuaian dengan platform citra satelit yang digunakan (Green et al., 2000).

Pengklasifikasian data lapangan berdasarkan kombinasi dari seluruh lokasi penelitian diperoleh jumlah kelas sebanyak 8 kelas yaitu pasir alga (PA), lamun (LM), alga (AL), pasir (PS), karang hidup (KH), rubble (RB), rubble lamun karang mati (RLKM), karang mati (KM). Skema klasifikasi data lapangan yang menghasilkan 8 kelas tersebut, selanjutnya dapat dilihat komposisi rata-rata penutupan habitat dari setiap kelas. Komposisi tersebut sebagaimana disajikan pada Figure 4.

Pada penelitian ini, hasil pengelompokkan kelas dari skema klasifikasi yang tidak memenuhi frekuensi kehadiran minimal $4 \%$ dari data input, dikelompokkan pada kelas yang memiliki nilai hampir sama dengan kelas yang telah dibentuk. Green et al. (2000) mengatakan bahwa skema klasifikasi yang menghasilkan kelompok kelas habitat bentik kurang dari $4 \%$ dari data input sebaiknya dihilangkan dan tidak digunakan untuk menentukan kelas habitat perairan dangkal pada proses klasifikasi dan validasi. Skema klasifikasi 6 dan 5 kelas ditetapkan dengan cara menggabungkan kelas habitat dengan kemiripan nilai penciri (spectral signature) dari hasil skema klasifikasi. Skema klasifikasi 6 kelas habitat, kelas habitat karang hidup $(\mathrm{KH})$ dan karang mati (KM) menjadi kelas karang (KR) serta kelas pasir alga (PA) dimasukan kedalam kelas pasir (PS). Sedangkan untuk skema klasifi- 


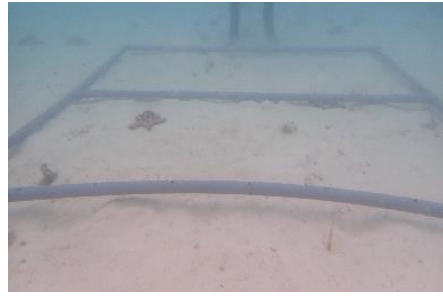

Sand

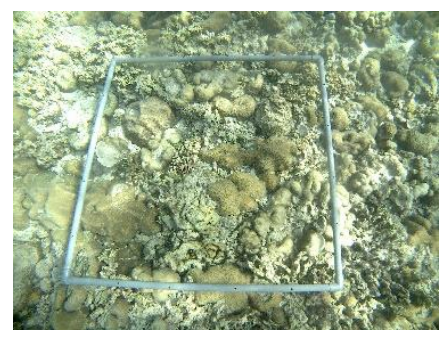

Death Coral

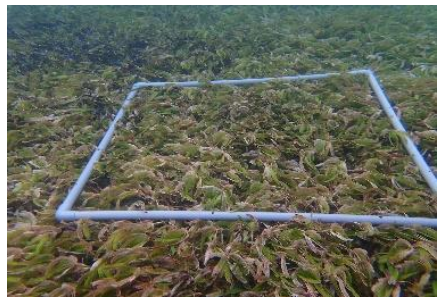

Seagrass

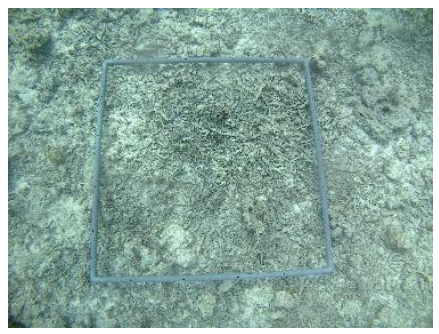

Rubble

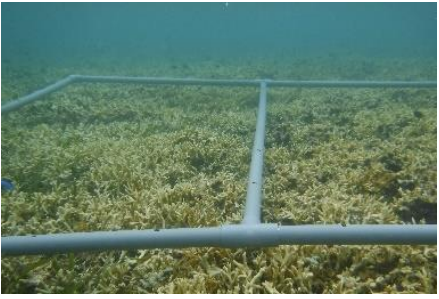

Live Coral

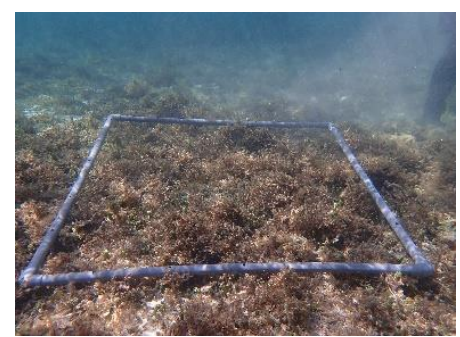

Algae

Figure 3. Benthic habitat percent cover.

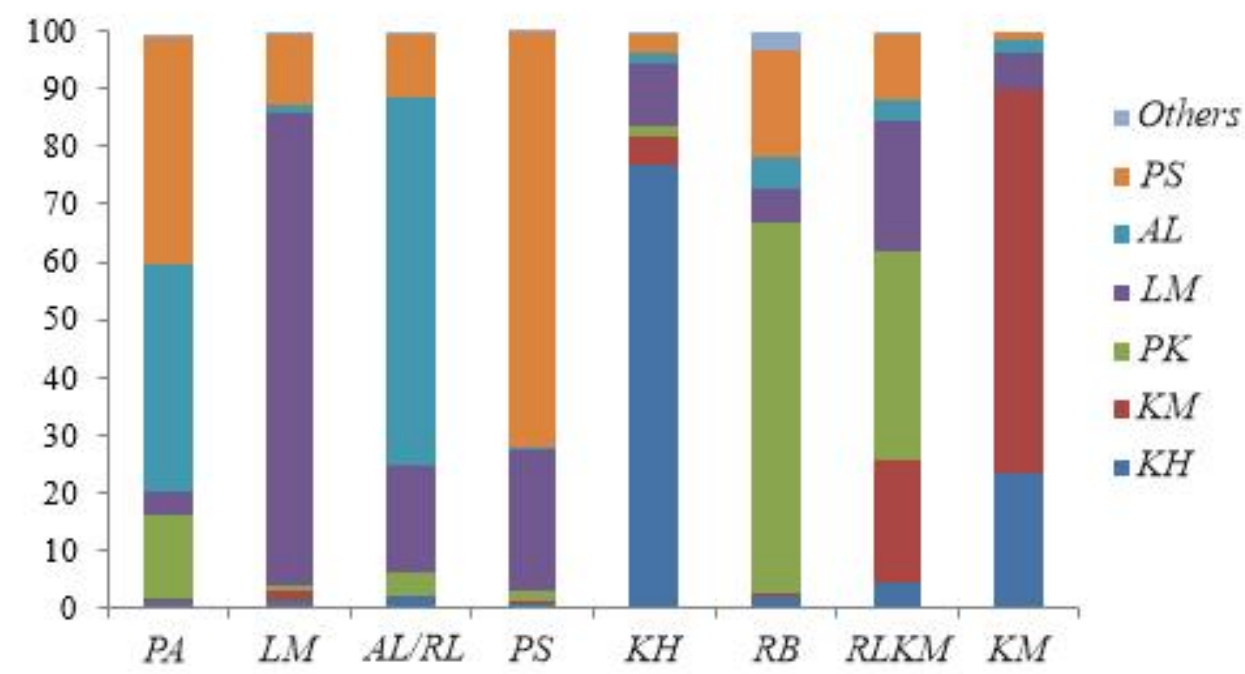

Figure 4. Benthic habitat classification scheme. Noted: Sand Algae (PA), Seagrass (LM), Algae/Seaweed (AL/RP), Sand (PS), Live Coral (KH), Rubble (RB), Rubble Seagrass Death Coral (RLKM), Death Coral (KM).

kasi 5 kelas habitat, berdasarkan skema klasifikasi 6 kelas habitat dengan menghilangkan kelas rubble lamun karang mati (RLKM).

\subsection{Klasifikasi Habitat Perairan Dangkal}

Sebelum melakukan proses pengklasifikasian habitat perairan dangkal pada citra satelit, maka dilakukan tahapan pra pengolahan. Hasil yang didapatkan adalah citra komposit pada kanal red-green-blue (RGB) yang telah terkoreksi radiometrik, geometrik, atmosferik, dan sun glint (Figure 5).

Hasil pengklasifikasian habitat perairan dangkal untuk citra satelit SPOT 6, Sentinel 2A, dan Landsat 8 menggunakan algoritma SVM disajikan pada Figure 6, Figure 7, dan Figure 8. Setiap warna mewakili masing-masing kelas habitat.

Pada Figure 6, 8 kelas habitat menunjukkan perbedaan yang signifikan diban- 
dingkan dengan sebaran habitat pada 6 kelas dan 5 kelas habitat. Kelas rubble lamun karang mati (RLKM) dan kelas pasir alga (PA) lebih dominan pada 8 kelas habitat, sedangkan pada skema klasifikasi dengan 6 kelas dan 5 kelas habitat mefnunjukkan hasil yang hampir sama di mana kelas pasir (PS) dan kelas lamun (LM) yang lebih dominan.

Figure 7 menunjukkan peta sebaran habitat perairan dangkal dengan 8,6 , dan 5 kelas pada Sentinel 2A. Hasil klasifikasi dari citra Sentinel 2A secara umum didominasi oleh kelas lamun (LM), kelas pasir (PS) dan kelas karang hidup (KH) (Figure 7). Skema klasifikasi dengan 8 kelas habitat menunjukkan adanya sebaran kelas rubble lamun karang mati (RLKM) yang terdapat di daerah sekitar lagoon dan tubir, sedangkan 6 dan 5 kelas habitat lebih bervariasi pada wilayah sekitar lagoon dan tubir serta memiliki hasil yang tidak berbeda signifikan.

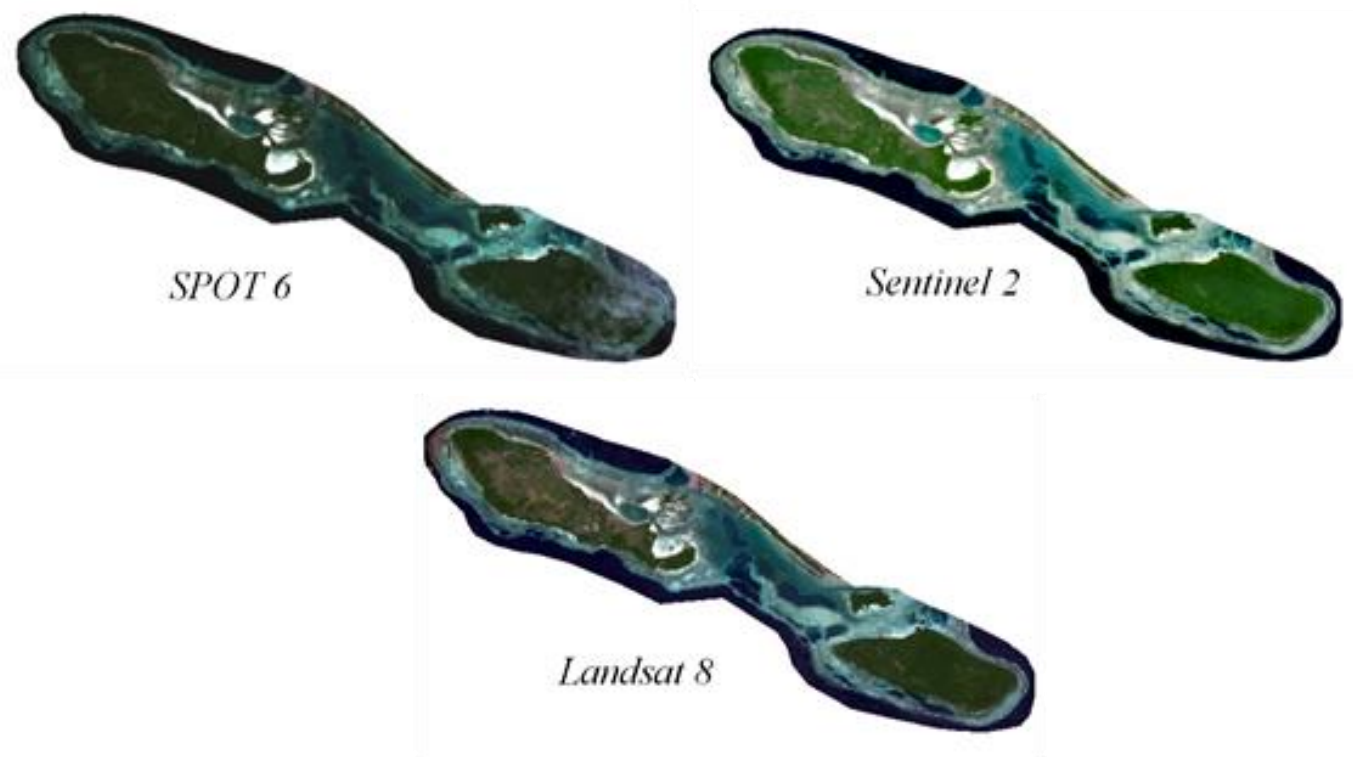

Figure 5. Pre Processed RGB Composite Image.

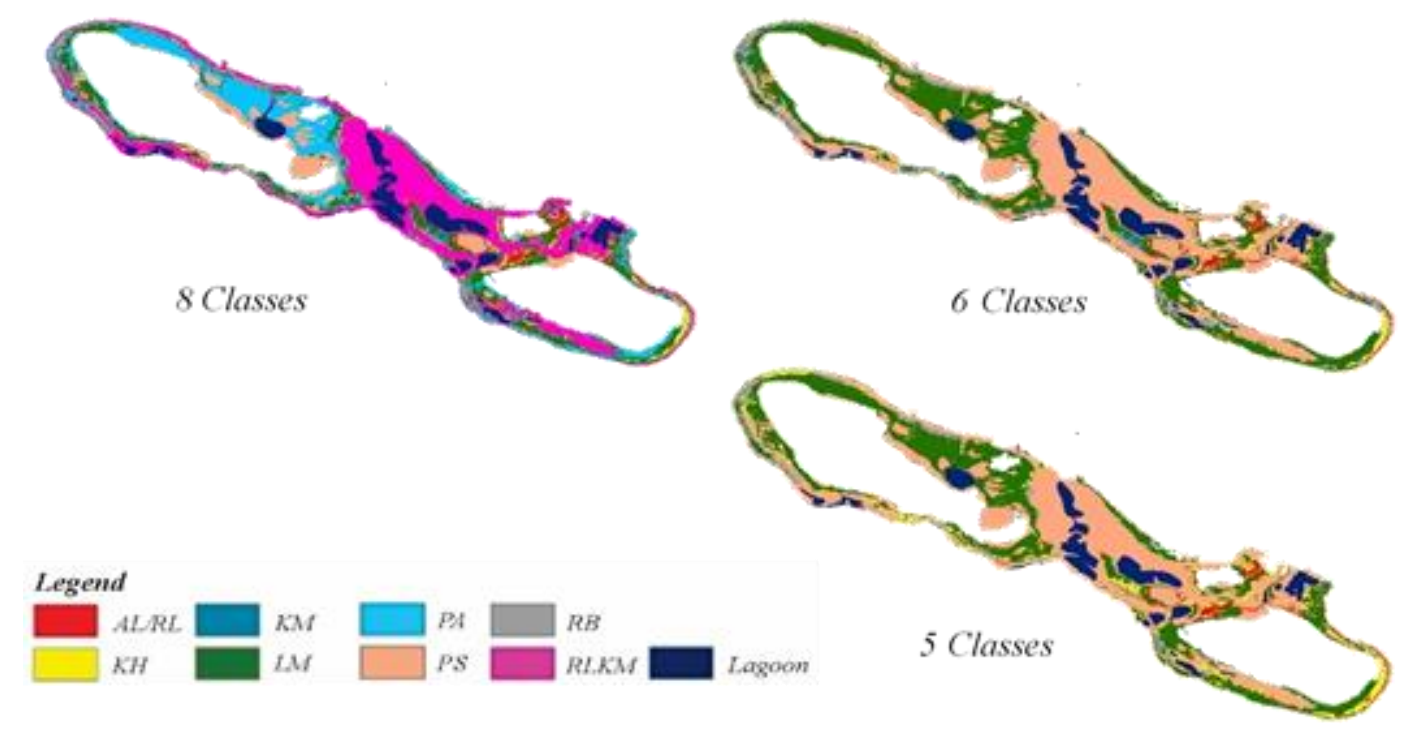

Figure 6. Benthic habitats classification in Kapota and Kampoone island using SPOT 6. 


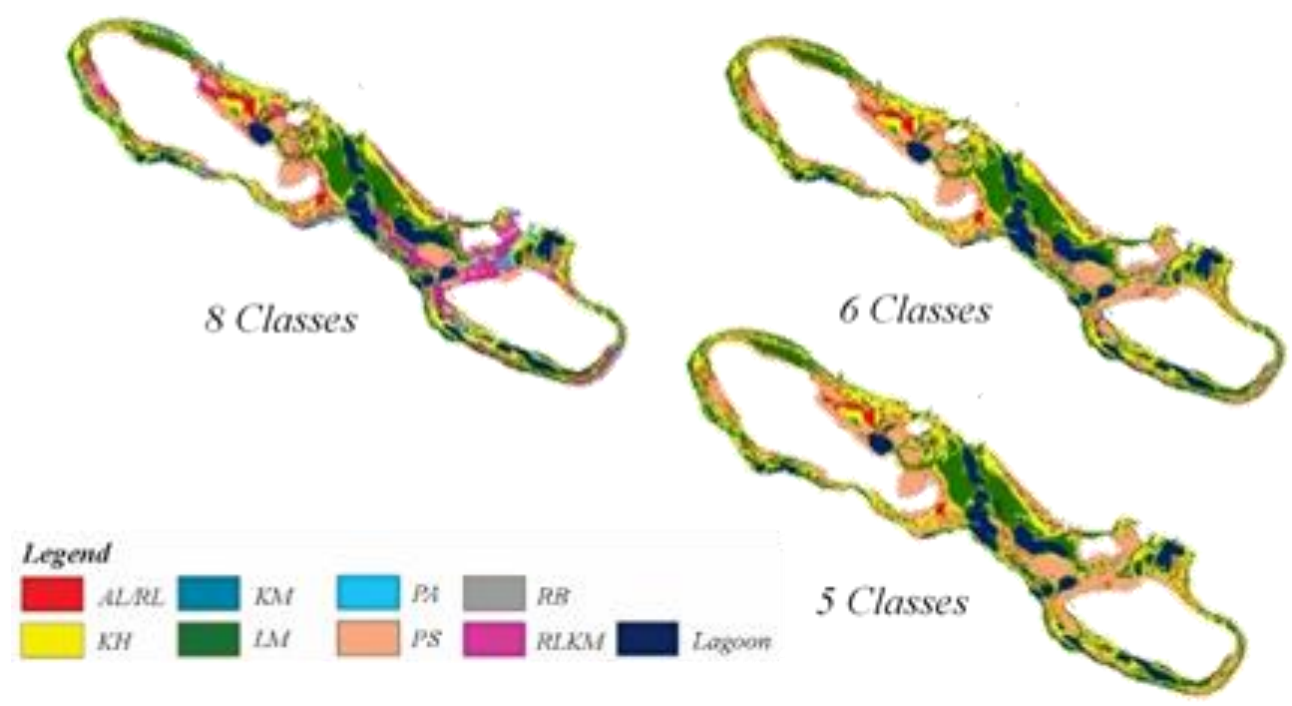

Figure 7. Benthic habitats classification in Kapota and Kampoone island using Sentinel $2 A$.

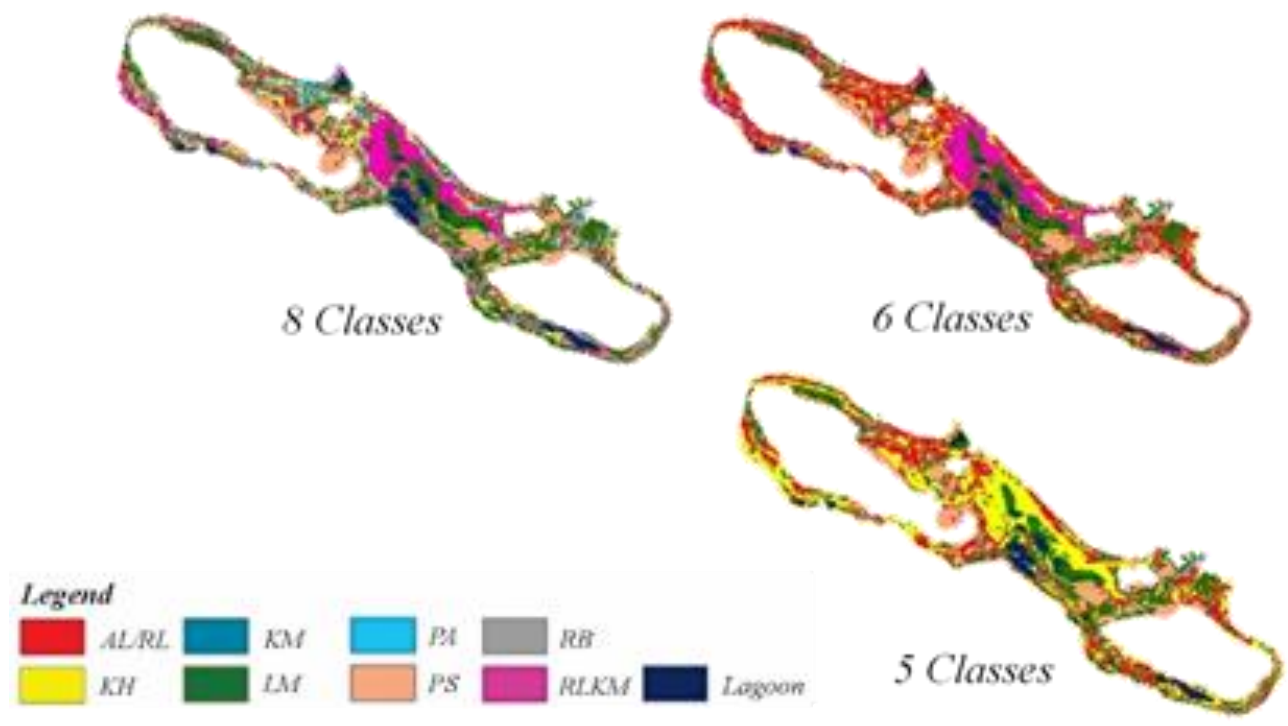

Figure 8. Benthic habitats classification in Kapota and Kampoone island using Landsat 8.

Figure 8 menunjukkan peta sebaran habitat perairan dangkal dengan 8,6 , dan 5 kelas pada Landsat 8. Hasil klasifikasi dengan 3 skema klasifikasi menggunakan algoritma SVM secara umum berbeda signifikan. Skema klasifikasi dengan 8 kelas menunjukkan kelas rubble lamun karang mati (RLKM) dan kelas lamun (LM) yang mendominasi. Sedangkan skema klasifikasi dengan 6 kelas, menunjukkan kelas alga/ rumput laut (AL/RL) dan kelas lamun (LM) yang mendominasi dan skema klasifikasi dengan 5 kelas habitat menunjukkan kelas alga/rumput laut (AL/RP) dan kelas karang (KR) yang mendominasi.

\subsection{Uji Akurasi Hasil Klasifikasi}

Uji akurasi hasil klasifikasi pemetaan sebaran habitat bentik pada citra SPOT 6, citra Sentinel 2A dan citra Landsat 8 dengan menggunakan algoritma SVM disajikan pada Table 2. Citra SPOT 6 dan citra Sentinel 2A menghasilkan nilai overall accuracy $>60 \%$, citra Landsat 8 menghasil- 
kan nilai overall accuracy $<50 \%$. Pada citra SPOT 6 untuk skema klasifikasi 8, 6 dan 5 kelas habitat masing-masing sebesar $70,35 \%, 75,58 \%$ dan 78,44\%. Sedangkan citra Sentinel 2A, masing-masing sebesar $66,66 \%, 70,28 \%, 72,72 \%$ dan citra Landsat 8 masing-masing sebesar $38,78 \%, 44,76 \%$ dan 49,69\% (Table 2).

Table 2. Result of overall accuracy from each satellite imageries.

\begin{tabular}{cccc}
\hline $\begin{array}{c}\text { Classification } \\
\text { Scheme }\end{array}$ & SPOT & Sentinel & Landsat \\
\hline 8 Classes & $70.35 \%$ & $66.66 \%$ & $88.78 \%$ \\
6 Classes & $75.58 \%$ & $70.28 \%$ & $44.76 \%$ \\
5 Classes & $78.44 \%$ & $72.72 \%$ & $49.69 \%$ \\
\hline
\end{tabular}

Nilai overall accuracy akan menurun seiring bertambahnya kelas habitat dan perbedaan resolusi spasial citra (Table 2). Sangadji et al. (2018) mengatakan bahwa keterbatasan resolusi data pengidraan jauh juga menjadi faktor pembatas dalam menghasilkan informasi, meskipun citra satelit mempunyai kemampuan yang baik dalam membedakan habitat pada tingkat kasar atau dengan jumlah kelas yang kecil. Citra SPOT 6 memiliki resolusi spasial sebesar $6 \mathrm{~m}$, citra Sentinel 2A sebesar $10 \mathrm{~m}$, dan citra Landsat 8 sebesar $30 \mathrm{~m}$. Hal ini juga dikatakan oleh Congalton \& Green (2008) bahwa kesalahan dalam pendugaan akurasi dapat disebabkan oleh beberapa faktor, yaitu kesalahan data referensi, sensitivitas skema klasifikasi pada variabilitas pengamat, ketidaksesuaian resolusi spasial data citra dan kesalahan dalam proses pemetaan.

Table 3 memperlihatkan nilai Kappa statistik dan varian Kappa dari masingmasing matriks kesalahan. Nilai Kappa tertinggi terdapat pada citra SPOT dan Sentinel 2A untuk 5 kelas habitat yaitu 0,72. Sedangkan terendah pada citra Landsat 8 untuk 8 kelas habitat, yaitu 0,28 . Nilai varian Kappa yang tertinggi untuk tiga citra dan tiga kelas habitat yaitu 0,0220 (Sentinel 2A: 5 kelas habitat) dan yang terendah adalah 0,0021 (SPOT 6: 8 kelas habitat). Kedua nilai tersebut dihitung untuk mendapatkan nilai $\mathrm{Z}$ statistik dari dua matriks kesalahan (Table 4). Selain itu, nilai Kappa meyatakan pengurangan kesalahan dalam klasifikasi acak dan berada pada rentang 0 hingga 1 . Biasanya akan lebih kecil dari overall accuracy (Congalton \& Green, 2008). Misalnya nilai $\mathrm{K}$ adalah 0,80 maka proses klasifikasi yang dilakukan menghindari $80 \%$ kesalahan (Congalton \& Green, 2008).

Nilai Z statistik merupakan uji statistik untuk menguji jika dua matriks kesalahan independen berbeda secara signifikan (Congalton \& Green, 2008). Nilai Z statistik untuk dua matriks kesalahan pada Table 4

Table 3. Varian Kappa and Kappa value from each error matrix.

\begin{tabular}{ccccccc}
\hline \multirow{2}{*}{$\begin{array}{c}\text { Number of } \\
\text { classes }\end{array}$} & \multicolumn{3}{c}{ Kappa $(K)$} & \multicolumn{3}{c}{ Varian Kappa $(\operatorname{var}(K))$} \\
\cline { 2 - 7 } & SPOT 6 & Sentinel 2 & Landsat 8 & SPOT 6 & Sentinel 2 & Landsat 8 \\
\hline 8 & 0.65 & 0.66 & 0.28 & 0.0021 & 0.0032 & 0.0065 \\
6 & 0.69 & 0.69 & 0.32 & 0.0027 & 0.0043 & 0.0081 \\
5 & 0.72 & 0.72 & 0.36 & 0.0028 & 0.0220 & 0.0095 \\
\hline
\end{tabular}

Table 4. Z statistic value from two different error matrix.

\begin{tabular}{cccc}
\hline Number of & \multicolumn{3}{c}{ Z Statistic } \\
\cline { 2 - 4 } classes & SPOT 6 vs Landsat 8 & SPOT 6 vs Sentinel 2A & Sentinel 2A vs Landsat 8 \\
\hline 8 & 4.06 & 8.43 & 2.21 \\
6 & 3.61 & 7.65 & 2.19 \\
5 & 3.17 & 3.87 & 2.33 \\
\hline
\end{tabular}


memiliki nilai masing-masing lebih dari 1,96. Jika nilai mutlak hasil tes $\mathrm{Z}$ statistik lebih besar dari -1,96 sampai 1,96 maka hasilnya adalah berbeda signifikan dan dikatakan signifikan jika hasil Z statistik antara 1,96 sampai 1,96 (Congalton \& Green 2008). Oleh karena itu, Tabel 4 menunjukkan nilai $\mathrm{Z}$ statitik untuk dua matriks kesalahan yang berbeda signifikan.

\section{KESIMPULAN}

Perbedaan ukuran piksel (resolusi spasial) dan banyaknya jumlah kelas (skema klasifikasi) dari citra satelit memengaruhi hasil akurasi di mana citra satelit SPOT 6 memiliki tingkat akurasi yang lebih besar dibandingkan dengan Sentinel 2A dan Landsat 8. Skema klasifikasi pada 5 kelas habitat memiliki tingkat akurasi yang lebih besar dibandingkan dengan 6 dan 8 kelas.

\section{UCAPAN TERIMA KASIH}

Ucapan terima kasih ditujukan kepada Direktorat Riset dan Pengabdian Masyarakat Ditjen Penguatan Riset dan Pengembangan Kementerian Riset, Teknologi, dan Pendidikan Tinggi, Republik Indonesia melalui program hibah Penelitian Dasar Unggulan Perguruan Tinggi (PDUPT) yang diketuai oleh Prof. Dr. Ir. Vincentius Paulus Siregar, DEA.

\section{DAFTAR PUSTAKA}

Benfield, S.L., H.M. Guzman, J.M. Mair, \& J.A.T. Young. 2007. Mapping the distribution of coral reefs and associated sublittoral habitats in Pacific Panama: a comparison of optical satellite sensors and classification methodologies. International J. of Remote Rens, 28(22): 5047-5070.

https://doi.org/10.1080/01431160701 258062
Capolsini, P., S. Andrefouet, C. Rion, C. Payri. 2003. A Comparison of Landsat ETM+, SPOT HRV, Ikonos, ASTER, and Airbone Master Data for Coral Reef Habitat Mapping in South Pasific Islands. J. Remote Sens., 29(2): 187-200. https://doi.org/10.5589/m02-088

Congalton, R.G. \& K. Green. 2008. Assessing the accuracy of remotely sensed data: principles and practices. CRC Taylor \& Francis Group. 183 p.

Doxani, G., M. Papadopulou, P. Lafaxani, \& M. Tsakiri-Strati. 2012. Shallowwater bathymetry over variable bottom types using multispectral worldview-2 image. International Archives of the Photogrammetry, Remote Sensing and Spatial Information Science, ISPRS, 39(8): 329-340.

https://doi.org/10.5194/isprsarchivesXXXIX-B8-159-2012

Eugenio, F., J. Marcello, \& J. Martin. 2015. High-resolution maps of bathymetry and benthic habitats in shallow-water environments using multispectral remote sensing imagery. IEEE Transactions on Geoscience and Remote Sensing, 53(7): 3539-3549. https://doi.org/10.1109/TGRS.2014.2 377300

Green, E.P., P.J. Mumby, A.J. Edwards, \& C.D. Clark. 2000. Remote sensing handbook for tropical coastal management. coastal management sourcebooks 3. In A.J. Edwards (Ed.) (p. $x+316$ ). Paris (FR). 316 p.

Harris, P. \& E.K. Baker. 2012. Seafloor Geomorphology as Benthic Habitat. GeoHAB Atlas of Seafloor Geomorphic Features and Benthic Habitats. Elsevier Inc. 888 p.

Hedley, J., C. Roelfsema, B. Koetz, \& S. Phinn. 2012. Capability of the sentinel mission for tropical coral reef mapping and coral bleaching 
detection. Remote Sens. of Environment, 120(2012): 145-155. https://doi.org/10.1016/jrse.2011.06. 028

Laffoley, D. \& G.D. Grimsditch. 2009. The Management of Natural Coastal Carbon Sinks. IUCN Press. Gland Switzerland. 53 p.

Lyons, M., S. Phinn, \& C. Roelfsema. 2011. Integrating quickbird multispectral satellite satelitte and field data: mapping bathymetry, seagrass cover, seagrass species and change in Moreton Bay, Australia in 2004 and 2007. Remote Sens., 3: 42-64. https://doi.org/10.3390/rs3010042

Mandanici, E. \& G. Bitelli. 2016. Preliminary comparison of sentinel $2 \mathrm{~A}$ and Landsat 8 Imagery for a combined use. Remote Sens., 8(1014): 1-10. https://doi.org/10.3390/rs8121014

Mastu, L.K., B. Nababan, \& J.P. Panjaitan. 2018. Pemetaan habitat bentik berbasis objek menggunakan citra Sentinel-2 di perairan Pulau WangiWangi, Kabupaten Wakatobi. J. Ilmu dan Teknologi Kelautan Tropis, 10(2): 381-396. http://doi.org/10.29244/jitkt.v10i2.21 039

Mountrakis, G., J. Im, \& C. Ogole. 2011. Support vector machines in remote sensing: A review. ISPRS J. Photogramm. Remote Sens., 66(3): 247-259.

https://doi.org/10.1016/j.isprsjprs.201 0.11 .001

Mumby, P.J., W. Skirving, A.E. Strong, J.T. Hardy, E.F. LeDrew, E.J. Hochberg, R.P. Stumpf, \& L.T. David. 2003. Review remote sensing of coral reefs and their physical environment. Marine Pollution Bulletin, 48: 210228.

https://doi.org/10.1016/j.marpolbul.2 003.10 .031
Prabowo, N.W., V.P. Siregar, \& S.B. Agus. 2018. Klasifikasi habitat bentik berbasis objek dengan algoritma support vector machine dan decision tree menggunakan citra multispektral SPOT-7 di Pulau Harapan dan Pulau Kelapa. J. Ilmu dan Teknologi Kelautan Tropis, 10(1): 123-134. http://doi.org/10.29244/jitkt.v10il.21 670

Pu, R., S. Bell, \& C. Meyer. 2014. Mapping and assessing seagrass bed changes in Central Florida's West Coast using Multitemporal Landsat TM Imagery. Estuarine, Coastal and Shelf Science, 149: 68-79. https://doi.org/10.1016/j.ecss.2014.0 7.014

Sangadji, M.S., V.P. Siregar, \& H.M. Manik. 2018. Klasifikasi habitat perairan dangkal menggunakan logika fuzzy dan maximum likelihood pada citra satelit multispektral. $J$. Ilmu dan Teknologi Kelautan Tropis, 10(3): 639-649.

http://doi.org/10.29244/jitkt.v10i3.22 859

Siregar, V.P., S.B. Agus, A. Sunuddin, T. Subarno, \& N.N. Aziizah. 2020. Analisis perubahan habitat dasar perairan dangkal menggunakan citra satelit resolusi tinggi di Karang Lebar, Kepulauan Seribu. J. Ilmu dan Teknologi Kelautan Tropis, 12(1): 37-51.

http://doi.org/10.29244/jitkt.v12i1.25 528

Traganos, D. \& P. Reinartz. 2017. Mapping mediterranean seagrass with sentinel2 Imagery. Marine Pollution Bulletin, 134: 197-209.

http://doi.org/10.1016/j.marpolbul.20 17.06.075

Wahidin, N., V.P. Siregar, B. Nababan, I. Jaya, \& S. Wouthuyzen. 2015. Object-based image analysis for coral reef benthic habitat mapping with several classification 
algorithms. Procedia Environmental Sciences, 24: 222-227.

https://doi.org/10.1016/j.proenv.2015 .03 .029

Wei, C., J. Huang, L.R. Mansaray, Z. Li, W. Liu, \& J. Han. 2017. Estimation and mapping of winter oilseed rape lai from high spatial resolution satellite data based on a hybrid method.

Remote Sens., 9(5): 1-16.

https://doi.org/10.3390/rs9050488

Received : 13 September 2020

Reviewed : 8 October 2020

Accepted : 15 December 2020 
